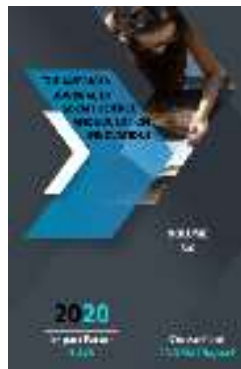

\title{
Investment Relations And Prospects Of South Korea And Uzbekistan
}

\author{
Ismoilova Feruza \\ Independent Researcher, The Department Of "Teaching Languages", Fergana Polytechnic \\ Institute, Fergana, Uzbekistan
}

Journal Website: http://usajournalshub.c om/index,php/tajssei

Copyright: Original content from this work may be used under the terms of the creative commons attributes 4.0 licence.

\section{ABSTRACT}

The relations of South Korea and Uzbekistan are discussed in terms of economic development while investment between two countries and its role on providing employment is seen as driving factor. The latest visits of two countries are taken as a proof to show the result with numbers.

\section{KEYWORDS}

Investment, intergovernmental, employment, enterprise, investor, supplying, world-class

\section{INTRODUCTION}

Since global economy is growing day by day, several attempts are being accomplished by the government in order to step properly and equally following the developing and developed states of the world. As far as it is known well, innovation and investment have been played main role as driving factors of improving economy in any period and place. In this term it is practical to follow or to choose the countries as a partner which has already overcome the difficulties and has already had own way of running investment. Taking everything into account, national government selected South Korea as a sister country. There are reasonable factors to choose this country and one of them is because Uzbekistan and South Korea are geographically distant, but close, with common goals for peace and development. Additionally, history has proved that our countries have been interacting since 
the time of the Great Silk Road. A vivid sample of this is the murals in the Afrosiyob Museum in Samarkand, which indicate the reception of the ancient Korean-Chosun ambassador by the governor of Samarkand in the middle of the 7 th century $[1,2]$.

\section{MAIN PART}

Our countries are time-tested and reliable strategic partners. As a result of high-level dialogue and joint efforts, the cooperation between our countries has been steadily developing in all directions. The state visit of the President of the Republic of Uzbekistan Shavkat Mirziyoyev to the Republic of Korea on November 22-25, 2017 raised the relations to a qualitatively new level. In order to strengthening the relations between two countries at the invitation of President of the Republic of Uzbekistan, President of the Republic of Korea Moon Jae-in arrived in our country on April 18, 2019 on a state visit [3].

It is undeniable fact that, this historic visit has laid a solid foundation for the development of multifaceted ties. During the visit, more than 20 intergovernmental, and interdepartmental agreements were signed, as well as 64 documents worth more than 10 billion US dollars. To compare with, the trade between us exceeded only $\$ 2.1$ billion. The amount of contract signed proves that, the state visit of the President of the Republic of Korea to Uzbekistan is an important event in the history of Uzbek-South Korean relations and serves to bring our countries and peoples closer.

When it comes to the share of South Korea's investors on the economy of Uzbekistan plays one of the most essential role in terms of providing employment chances in our country. As there are 660 enterprises with South
Korean investors operating in Uzbekistan about 354 of them are fully funded by foreign capital which means the national government is grateful not only for being provided with vacancies but also spending almost nothing to run the business. This indicates the development of trade and investment cooperation between businessmen are being cherished of the two countries.

Furthermore and even more importantly, there are 75 companies registered in our country. In 2018, the Uzbek-Korean Chamber of Commerce opened in Incheon. It plays an important role in supplying world-class Uzbek products to the South Korean market. South Korea has welcomed reforms in Uzbekistan to liberalize the economy and improve the investment climate. This will increase the inflow of investment and high technology into the country, produce value-added products and create permanent jobs.

President Shavkat Mirziyoyev noted that Uzbekistan is interested in expanding cooperation in energy, oil and gas, chemistry, mining, transport and logistics, implementation of promising projects in engineering, electrical engineering, textile and food industries, infrastructure development . He stressed that South Korean companies will be supported in every way to make them feel free and comfortable in our country. The talks focused on new opportunities in these areas and proposals for their implementation. It was agreed to continue the establishment of enterprises in the leading sectors of the economy, free economic zones and small industrial zones of the country, the development of "e-government", training in innovation and social spheres [2-5]. 
The total volume of South Korean investments in the economy of our country has exceeded \$ 7 billion so far. The Korean National Petroleum Corporation, Eximbank, Kogas, Lotte Group, Samsung, Hyundai, Shindong Resources and many other leading companies are actively involved in the implementation of major investment projects in our country which means thousands of Uzbek people are employed.

The business forum discussed issues of expanding investment cooperation between companies and organizations of the two countries, development and implementation of new projects, supply of goods and services. Agreements worth more than $\$ 12$ billion. These include energy, oil and gas, chemicals, mining, machinery and electrical engineering, transportation and logistics, textiles and food industries, infrastructure, information and communication technologies, and digital medicine.

\section{CONCLUSION}

Taking foregoing evidents into account it can be concluded that cooperation between two countries can lead our country to improve the productivity in all spheres. The amount invested by Korean businessmen and Korean government will be considered as a huge contribution on developing Uzbek economy. It would be suggested that teaching "What the investment is?" and "The importance of investment" to the students of each department at Higher Educational Institutions could be another solution for the further progress in Uzbekistan. In view of the fact that all students may have a business ability in their inside and the knowledge acquired at University can lead them to run their own line of work linked with the investment either international or domestic trade.

\section{REFERENCES}

1. UzA. (n.d.). Relations between Uzbekistan and South Korea have risen to the level of a separate strategic partnership. Uzembassy.Kz. Retrieved April 19, 2019, from http://www.uzembassy.kz/uz/article/ uzbekistan-and-south-korea-relationsseparate-strategic-partnership-levelsecretary

2. Koreapost. (2019, September 19). Korea, Uzbekistan upgrade bilateral relations to a special strategic partnership.

Http://Www.Koreapost.Com/. http://www.koreapost.com/news/artic leView.html?idxno=10045

3. france24. (2019, April 19). Uzbekistan, S.Korea sign deals worth \$12bn during Moon visit. France 24. https://www.france24.com/en/2019041 9-uzbekistan-skorea-sign-deals-worth12bn-during-moon-visit

4. Ismoilova, F. A. (2019). Applying video material in teaching a foreign language. Problems of modern science and education, (12-2), 118-120. 